\title{
Anti-Inflammatory Gene Therapy Improves Spatial Memory Performance in a Mouse Model of Alzheimer's Disease
}

\author{
Tai June Yoo $^{\mathrm{a}, \mathrm{b}, *}$ \\ ${ }^{a}$ Korea Allergy Clinic, KangNam Gu, Seoul, South Korea \\ ${ }^{\mathrm{b}}$ University of Tennessee Health Science Center, Memphis, TN, USA
}

Accepted 12 November 2021

Pre-press 9 December 2021

\begin{abstract}
The immune system plays a critical role in neurodegenerative processes involved in Alzheimer's disease (AD). In this study, a gene-based immunotherapeutic method examined the effects of anti-inflammatory cellular immune response elements (CIREs) in the amyloid- $\beta$ protein precursor ( $\mathrm{A} \beta \mathrm{PP})$ mouse model. Bi-monthly intramuscular administration, beginning at either 4 or 6 months, and examined at 7.5 through 16 months, with plasmids encoding Interleukin (IL)-10, IL-4, TGF- $\beta$ polynucleotides, or a combination thereof, into A $\beta P P$ mice improved spatial memory performance. This work demonstrates an efficient gene therapy strategy to downregulate neuroinflammation, and possibly prevent or delay cognitive decline in AD.
\end{abstract}

Keywords: Alzheimer's disease, amyloid- $\beta$ protein precursor, genetic therapy, immunotherapy, interleukin-10, interleukin-4, neuroinflammation, spatial memory, transgenic mice, transforming growth factor beta

\section{INTRODUCTION}

Alzheimer's disease (AD), the most common form of dementia, is not a normal part of aging, but rather a chronic neurodegenerative pathology associated with neuroinflammation, extracellular amyloid- $\beta$ (A $\beta)$ plaques, and hyperphosphorylated tau, which leads to progressive cognitive decline in older adults [1-3]. The specific cause of AD remains unclear, but it may collectively involve the accumulation of activated microglia, astrocytes, and proliferative $\mathrm{T}$ cells which target extracellular filamentous abnormal $\mathrm{A} \beta$ protein deposits in the brain [4-7]. Although most neurodegenerative diseases are not classically considered autoimmune, in some instances, chronic neuroinflammation in aging can exacerbate a progressively

\footnotetext{
*Correspondence to: Tai June Yoo, Korea Allergy Clinic, KangNam Gu, Seoul, South Korea. E-mail: professortjyoo@gmail.com.
}

declining innate immune system leading to further neuronal damage $[8,9]$.

The adaptive immune system can be broadly classified into two types of inflammatory activity: cellular and humoral (antibody). Among cytokine responses, proinflammatory $\mathrm{T}$ helper type 1 (Th1) (i.e., interferon-gamma (IFN- $\gamma$ ), tumor necrosis factor (TNF- $\alpha$ ), IL-1, IL-2, IL-12), an anti-inflammatory Th2 (i.e., IL-4, IL-5, IL-10, IL-13), Th3 (TGF- $\beta$ ), and Th17 are involved in neurodegenerative disease and could be targeted for therapy. Moreover, antiinflammatory CIREs such as IL-10 and TGF- $\beta$ play a critical role in neurodegenerative autoimmune diseases such as multiple sclerosis, Parkinson's disease, and amyotrophic lateral sclerosis [10-14]. Although immunotherapeutic clinical trials were previously halted, emerging work continues to corroborate the importance of $\mathrm{T}$ cell recognition and autoimmune susceptibility in the etiology of AD [15-17]. 
For patients experiencing mild cognitive impairment, an elevated presence of proinflammatory TNF- $\alpha$ concurrent with decreased anti-inflammatory TGF- $\beta$ levels was observed, resulting in a greater risk conversion towards AD [18]. Similarly, TNF- $\alpha$ and other proinflammatory cytokines such as IL-1 $\beta$ and IL-6 were reported to impact anti-inflammatory processes and increase amyloid brain deposition in transgenic $\mathrm{AD}$ mice [19-21], with the latter cytokine driving blood-brain barrier dysfunction [22]. Anti-inflammatory cytokines, IL-4 and IL-10, have also garnered therapeutic interest due to their immunomodulatory role in the autoreactive $\mathrm{T}$ cell repertoire of neurodegenerative diseases [23-25]. Researchers evaluating IL-4 and IL-10 polymorphisms in patient populations have reported that a relative paucity of the genetic disruptions in these Th2 cytokines increases susceptibility to developing AD [26-31]. Therefore, the specific role these and other anti-inflammatory cytokines play in preventing or ameliorating neurodegeneration in AD not only warrants further investigation, but also requires new experimental approaches.

For example, gene-based technologies could provide a promising therapeutic strategy to ameliorate neurodegenerative disease due to administration ease, an efficacious and safe profile, and long-lasting effects [32-35]. Previous Yoo laboratory gene transfer work, examining anti-inflammatory response using a clinically relevant allergen to induce experimental autoimmune hearing loss, was successful in controlling autoimmune reaction severity through suppression of Th1-type proinflammatory responses and inducing IL-10-secreting regulatory $\mathrm{T}$ cells [36]. This non-toxic naked DNA delivery technique suggests exogenous IL-10 could restore immunological homeostasis by suppressing the autoimmune response and generate an endogenous regulatory IL-10 profile. Since chronic inflammation appears to trigger $\mathrm{T}$ cell-mediated autoimmune disease, the present study assessed whether anti-inflammatory CIRE gene therapy could also improve spatial memory performance in the amyloid- $\beta$ protein precursor $(A \beta P P)$ mouse, and thus prevent or delay $\mathrm{AD}$ onset.

\section{MATERIALS AND METHODS}

\section{Transgenic animals}

Transgenic mice (Tg-2576) containing the K670N/ M671L (AßPP) Swedish double mutation, which leads to familial early onset AD [37], were obtained from The Jackson Laboratory (Bar Harbor, ME, U.S.A.) and maintained at the University of Tennessee, Memphis animal facility after experimental approval by the Institutional Animal Care and Use Committee of the University of Tennessee.

\section{Plasmid DNA preparation and transfection reagents}

Polynucleotide constructs under a simian virus 40 promoter encoding a CIRE were used: IL-4, IL10, TGF- $\beta$ (i.e., GenBank Accession No. M13982, 55 SEQ ID NO:12), (M57627, SEQ ID NO:14), (M60316, SEQ ID NO:16), respectively. Expression of CIRE naked DNA plasmids utilized the pVAX1 vector (Invitrogen, Carlsbad, CA) and cytomegalovirus promoter/enhancer sequences. A control vector without the CIRE genes was developed by digesting related plasmid DNA with EcoRI, followed by ligating the agarose gel-purified vector fragment. Large-scale purification of all plasmid DNA was conducted with Endo Free Plasmid Maxi kits (Qiagen, Valencia, CA). Methodology was reported [38-42], with dosage effective at least 1-5 weeks after injection, and adopted from previous studies [36, 43]. Male and female A $\beta P P$ mice were bimonthly, intramuscularly injected with either $100 \mu \mathrm{g}$ of a blank vector in $100 \mu$ l of phospate-buffered saline for control or the same amount of naked DNA encoding CIREs. Mice were used or maintained until age 60 weeks, then sacrificed, brains removed, snap-frozen in liquid nitrogen, and stored at $-80^{\circ} \mathrm{C}$.

\section{Spatial memory performance evaluation in untreated and treated $A \beta P P$ mice}

Spatial learning and memory were assessed using the Morris Water Maze task [44] in a circular tank ( $80 \mathrm{~cm}$ wide, $80 \mathrm{~cm}$ deep) with a non-distinct submerged central platform $(15 \mathrm{~cm}$ wide, $1 \mathrm{~cm}$ below opaque water, $23^{\circ} \mathrm{C}$ ) (Fig. 1). All trials were recorded with an overhead camera. Maximum swim time for each trial was 90 s followed by a 20-s platform rest. Each mouse was trained for five days, four trials per day with randomized starting points. Probe trials were performed without the platform $30 \mathrm{~min}$ after the last trial. Mice were released opposite the target quadrant and allowed $60 \mathrm{~s}$ to swim. Following retraining (day 7 ), the platform was moved to the opposite quadrant for reversal training (days 8-10). A retention test was conducted $30 \mathrm{~min}$ after the last acquisition trial, and latency (seconds to platform) was registered 


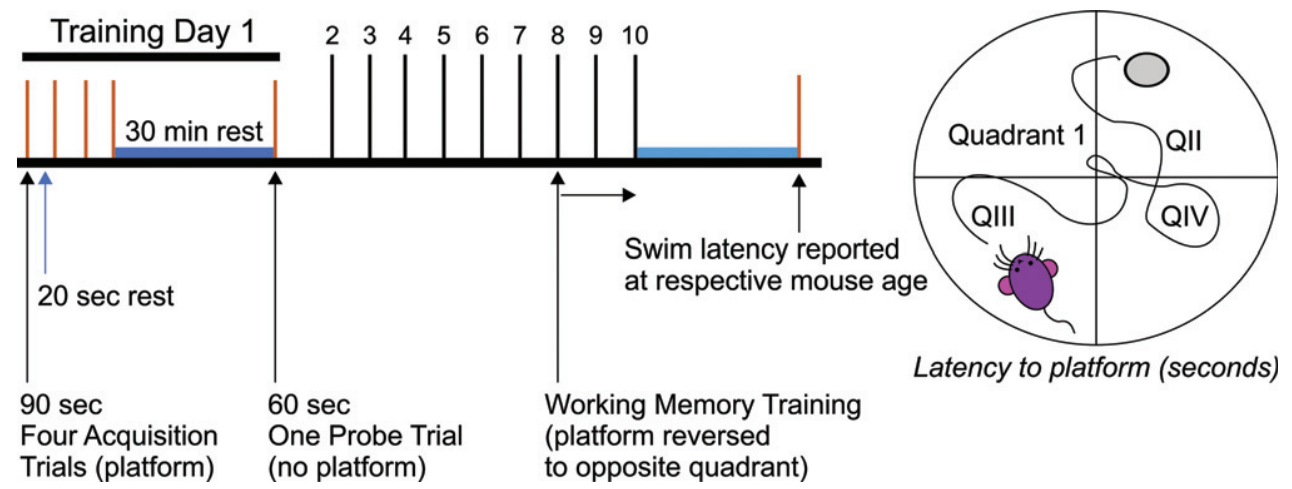

Fig. 1. Evaluation of spatial memory in A $\beta P P$ mice using the Morris Water Maze. The MWM is an intermittently sensitive test to evaluate reference memory performance for A $\beta P P$ mice [47].

Table 1

Morris Water Maze results of 7.5 through 16 months with bi-monthly DNA-based immunotherapy beginning either at 4 or 6 months of age in $A \beta P P$ mice

\begin{tabular}{|c|c|c|c|c|c|c|c|}
\hline Testing Age (month) & 7.5 & 8 & 9 & 9.5 & 11 & 13 & 16 \\
\hline Normal Untreated Mouse & 6 & 6 & 6 & d.n.r & d.n.r & 6 & 6 \\
\hline $\mathrm{A} \beta \mathrm{PP}$ control vector & 120 & 120 & 160,52 & 144,52 & 144 & 220,100 & 62 \\
\hline $\mathrm{A} \beta \mathrm{PP}+\mathrm{TGF}-\beta$ & 23 & 23 & 80,70 & 72,66 & 78,6 & 80,30 & 14 \\
\hline $\mathrm{A} \beta \mathrm{PP}+\mathrm{IL}-10$ & 15 & 15 & $8,7,15$ & 8,7 & 2,7 & $1,1,8$ & 3,4 \\
\hline $\mathrm{A} \beta \mathrm{PP}+\mathrm{IL}-4$ & d.n.r & d.n.r & 10 & 10 & 10 & 10 & 4 \\
\hline $\mathrm{A} \beta \mathrm{PP}+(\mathrm{IL}-10$ + IL-4) & d.n.r & d.n.r & d.n.r & d.n.r & d.n.r & 1,2 & 3 \\
\hline $\mathrm{A} \beta \mathrm{PP}+(\mathrm{IL}-10+\mathrm{TGF}-\beta)$ & d.n.r & d.n.r & d.n.r & d.n.r & d.n.r & 45,44 & d.n.r \\
\hline
\end{tabular}

Normal Untreated Mice $(n=5)$, A $\beta P P$ control vector $(n=10)$, TGF- $\beta(n=11)$, IL-10 $(n=14)$, IL-4 $(n=5)$, IL-10 + IL-4 ( $n=3)$, and IL$10+\operatorname{TGF}-\beta(n=2)$ latencies for individual mice were registered and indicated by numerical values. d.n.r., data not recorded.

(Table 1). Combined cytokine-treated animals were only tested at 13 and 16 months of age.

\section{Data analysis}

Latency times with animals $(n \geq 7)$ administered with CIREs beginning at 6 months were measured at specific ages $(7.5,9.5,11,13,16$ months) and analyzed by Welch's $t$-test and one-way ANOVA with Tukey HSD Post Hoc in $R$ open source software (https://cran.case.edu/) [45]. Threshold values of $p=0.05$ were considered statistically significant.

\section{RESULTS}

Early and late TGF- $\beta, I L-10$, or IL-4 gene therapy prevent and ameliorate A $\beta P P$ mice memory deficits

Mice injected bi-monthly with naked DNA encoding TGF- $\beta$, IL-10, or IL-4 beginning at 4-months of age ( $8 \& 9$ months columns), when hippocampal lesions begin to appear in the AßPP model, and tested in the MWM at 8 or 9 months (when lesions fully form [46]) reduced latency times to platform compared to age-matched A $\beta P P$ mice receiving a control blank vector (Table 1). Interestingly, A $\beta P P$ mice receiving either TGF- $\beta$, IL-10, or IL-4, or a CIRE gene combination bi-monthly beginning at 6 months, and examined at 7.5 through 16 months, also reduced latency-to-platform behavior. Overall, A $\beta P P$ mice administered TGF- $\beta$, IL-10, or IL- 4 naked DNA performed significantly better compared to A $\beta P P$ controls $(p=0.014,0.002$, and 0.002 , respectively; Fig. 2). No significant difference was observed between Normal Untreated (not illustrated) and IL-10 or IL-4 treated mice ( $p=0.777,0.194$, respectively).

\section{DISCUSSION}

The present study demonstrates that gene-based immunotherapy, with pleiotropic anti-inflammatory cytokines IL-10, IL-4, or TGF- $\beta$ improves spatial memory performance in a mouse model of $\mathrm{AD}$. A $\beta P P$ mice treated bi-monthly, beginning at age 


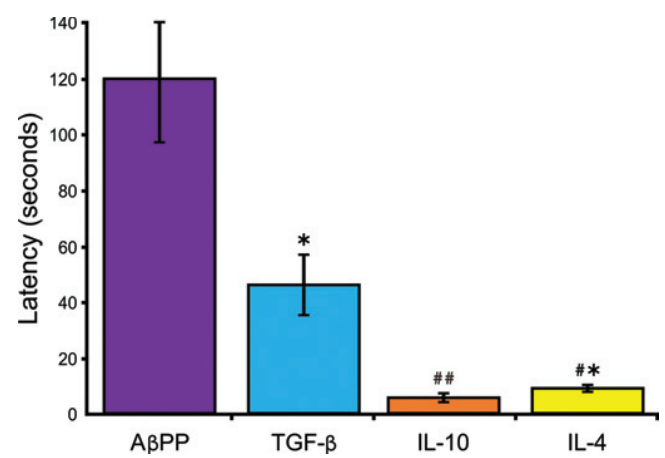

Fig. 2. A $\beta P P$ mice treated with TGF- $\beta$, IL-10, or IL-4 improves spatial memory. AßPP mice injected bi-monthly, beginning at 6 months, with either TGF- $\beta(n=8)$ or IL-10 $(n=10)$ and tested at $7.5,9.5,11,13$, and 16 months showed significant difference compared to A $\beta P P$ mice receiving control vector $(n=7)$ $[F(2,22)=22.69, p<0.001)]$. A PPP mice administered IL-4 $(n=4)$ also reduced swim latency compared to TGF- $\beta(p=0.011)$. Mean \pm S.E.M., Welch's $t$ test; ${ }^{*} p<0.05,{ }^{\#} p<0.01$.

4 or 6 months, with a single CIRE dose (or a combination thereof, in older animals) (Table 1), rescued an AD-associated behavioral phenotype. Although AD mouse models, including over 300 therapeutic investigations with the Tg-2576 line [48], presented pre-clinical limitations which resulted in untoward clinical trial outcomes [49-51], nevertheless still comprise $\sim 45 \%$ of $\mathrm{AD}$ drug development and continue to provide insight on temporal cell signaling in neurodegenerative disease [52, 53].

For instance, hippocampal IL-10 or IL-4 overexpression through an adeno-associated virus (AAV) in amyloid precursor protein+presenilin-1 bigenic mice increases neurogenesis and improves cognition without affecting hippocampal beta-amyloidosis [54, 55]. A separate group also reported that AAV-IL4 induced an anti-inflammatory response from an alternative activated macrophage phenotype while stimulating microglia and astrogliosis [56]. However, in two different AD models, IL-10- and IL-4-AAV modification increased hippocampal and cortical $A \beta$ accumulation and impaired memory, resulting in aberrant innate immune amyloidosis [57-59]. While viral vector technology for neuronal system delivery advances, introducing exogenous $\mathrm{Th} 2$ cytokine into a chronically inflamed system may unintentionally exacerbate and accelerate neuropathology [60-63]. Precise therapeutic intervention may be required. As an example, non-viral immunotherapy for AD could utilize the appropriate biomolecule, adjuvant and dose based on the patient's metabolic and stratified risk profile $[64,65]$.
Although anti-inflammatory gene therapy, in the present report, improved overall spatial memory deficits in AßPP mice, it remains unclear whether the corresponding cytokine levels increased in the periphery and/or neuronal tissue with the given dose. Previous experiments in the Yoo laboratory confirmed, through harvested splenocyte cultures and cochlear histology of IL-10 ${ }^{-/}$mice with experimental autoimmune hearing loss, that intramuscular injection of $100 \mu \mathrm{g}$ IL-10 DNA provided sufficient peripheral and cranial IL-10 production [36]. Interestingly, proinflammatory-induced neurodegeneration in an $\mathrm{AD}$ rat model was also alleviated in a dose-dependent manner with TGF- $\beta$ [66]. Notably, combinatorial TGF- $\beta$ /IL-10 plasmid DNA immunotherapy has already been explored to treat humoral autoimmune diseases [67]. Safe, novel, and optimized gene-based neuroimmunotherapies will be essential as drug development advances [68-70].

In oncology, 'cytokine synergy' infers that combined therapeutic potency is greater than any of the individual cytokines alone [71]. Intriguingly, older mice administered IL-10 + IL-4, and to a lesser extent IL-10 + TGF- $\beta$, could augment spatial memory in $A \beta P P$ mice (Table 1), suggesting synergistic anti-inflammatory $\mathrm{AD}$ amelioration. Additionally, plasmid delivery of DNA encoding IL-10/IL-4 prevents autoimmune diabetes in nonobese diabetic mice [72], while fusion protein treatments with these Th2 cytokines alleviates inflammatory pain $[73,74]$. Currently, inflammation in these concomitant diseases exacerbates cognitive decline [75-79], but synergistic cytokine gene therapy could provide health benefits not only for the aging population, but society as a whole.

Finally, AD mouse models exhibit anxiety, age/ gender performance variability, elevated retinal $\mathrm{A} \beta$, increased proinflammatory Th1 cytokines, and early-onset biomarker absence, which may confound behavioral data [53, 80-85]. Despite their putatively dubious nature, gene-based immunotherapy research in transgenic mice should continue exploring enhanced delivery systems and promoters, complementing adjuvants, and confirmation of experimental results in other AD models, such as rabbits, where artificially-induced risks factors are closer to human AD [86-90]. Furthermore, clinical trials for neurodegenerative disease involving naked DNA require more investment due to plasmid DNA biocompatibility, lower manufacturing cost, efficient production, and storage stability [91-93]. In summary, the present study provides an efficient 
strategy of preventing/delaying $\mathrm{AD}$ onset through down regulation of chronic inflammation using gene therapy.

\section{ACKNOWLEDGMENTS}

Funding was provided by Hearing Health Foundation (formerly, Deafness Research Foundation) New York, NY, USA; Veterans Administration Medical Center Memphis, TN, USA; and R01 Grant from NIH-NIDCDRO1-DCO05010-01-A2.

Related United States Patent: 8,247,385 B2 AUG, $21,2012$.

Plasmid DNA encoding murine IL-10 was a gift from Barry T Rouse, PhD, University of Tennessee, Knoxville, TN; experimental support provided by Mohammad Habiby Kermany, MD/PhD

Gregory J. Villareal, Ph.D. provided editorial support.

The author's disclosure is available online (https:// www.j-alz.com/manuscript-disclosures/21-5270r2).

\section{REFERENCES}

[1] Heneka MT, Carson MJ, El Khoury J, Landreth GE, Brosseron, F, Feinstein DL, Jacobs AH, Wyss-Coray T, Vitorica J, Ransohoff RM, Herrup K, Frautschy SA, Finsen B, Brown GC, Verkhratsky A, Yamanaka K, Koistinaho J, Latz E, Halle A, Petzold GC, Town T, Morgan D, Shinohara ML, Perry VH, Holmes C, Bazan NG, Brooks DJ, Hunot S, Joseph B, Deigendesch N, Garaschuk O, Boddeke E, Dinarello CA, Breitner JC, Cole GM, Golenbock DT Kummer MP (2015) Neuroinflammation in Alzheimer's disease. Lancet Neurol 14, 388-405.

[2] Selkoe DJ, Hardy J (2016) The amyloid hypothesis of Alzheimer's disease at 25 years. EMBO Mol Med 8, 595-608.

[3] Long JM, Holtzman DM (2019) Alzheimer disease: An update on pathobiology and treatment strategies. Cell 179, 312-339.

[4] Monsonego A, Zota V, Karni A, Krieger JI, Bar-Or A, Bitan G, Budson AE, Sperling R, Selkoe DJ, Weiner HL (2003) Increased $\mathrm{T}$ cell reactivity to amyloid beta protein in older humans and patients with Alzheimer disease. J Clin Invest 112, 415-422.

[5] Fisher Y, Nemirovsky A, Baron R, Monsonego A (2010) $\mathrm{T}$ cells specifically targeted to amyloid plaques enhance plaque clearance in a mouse model of Alzheimer's disease. PLoS One 5, e10830.

[6] Orre M, Kamphuis W, Osborn LM, Jansen A, Kooijman L, Bossers K, Hol EM (2014) Isolation of glia from Alzheimer's mice reveals inflammation and dysfunction. Neurobiol Aging 35, 2746-2760.

[7] Fakhoury M (2018) Microglia and astrocytes in Alzheimer's disease: Implications for therapy. Curr Neuropharmacol 16, 508-518.

[8] Amor S, Peferoen LA, Vogel DY, Breur M, van der Valk P, Baker D, van Noort JM (2014) Inflammation in neurodegenerative diseases-an update. Immunology 142, 151-166.
[9] Guzman-Martinez L, Maccioni RB, Andrade V, Navarrete LP, Pastor MG, Ramos-Escobar N (2019) Neuroinflammation as a common feature of neurodegenerative disorders. Front Pharmacol 10, 1008.

[10] Martinez Doncel A, Rubio A, Arroyo R, de las Heras V, Martín C, Fernandez-Arquero M, de la Concha EG (2002) Interleukin-10 polymorphisms in Spanish multiple sclerosis patients. J Neuroimmunol 131, 168-172.

[11] Li D, Song X, Huang H, Huang H, Ye Z (2018) Association of Parkinson's disease-related pain with plasma interleukin1 , interleukin-6, interleukin-10, and tumour necrosis factor$\alpha$. Neurosci Lett 683, 181-184.

[12] Porro C, Cianciulli A, Panaro MA (2020) The regulatory role of IL-10 in neurodegenerative diseases. Biomolecules 10, 1017.

[13] Strickland MR, Ibanez KR, Yaroshenko M, Diaz CC, Borchelt DR, Chakrabarty P (2020) IL-10 based immunomodulation initiated at birth extends lifespan in a familial mouse model of amyotrophic lateral sclerosis. Sci Rep 10, 20862.

[14] Lindestam Arlehamn CS, Dhanwani R, Pham J, Kuan R, Frazier A, Rezende Dutra J, Phillips E, Mallal S, Roederer M, Marder KS, Amara AW, Standaert DG, Goldman JG, Litvan I, Peters B, Sulzer D, Sette A (2020) $\alpha$-Synuclein-specific T cell reactivity is associated with preclinical and early Parkinson's disease. Nat Commun 11, 1875.

[15] Togo T, Akiyama H, Iseki E, Kondo H, Ikeda K, Kato M, Oda T, Tsuchiya K, Kosaka K (2002) Occurrence of T cells in the brain of Alzheimer's disease and other neurological diseases. J Neuroimmunol 124, 83-92.

[16] Orgogozo JM, Gilman S, Dartigues JF, Laurent B, Puel M, Kirby LC, Jouanny P, Dubois B, Eisner L, Flitman S, Michel BF, Boada M, Frank A, Hock C (2003) Subacute meningoencephalitis in a subset of patients with $\mathrm{AD}$ after Abeta42 immunization. Neurology 61, 46-54.

[17] Lindestam Arlehamn CS, Garretti F, Sulzer D, Sette A (2019) Roles for the adaptive immune system in Parkinson's and Alzheimer's diseases. Curr Opin Immunol 59, 115-120.

[18] Tarkowski E, Andreasen N, Tarkowski A, Blennow K (2003) Intrathecal inflammation precedes development of Alzheimer's disease. J Neurol Neurosurg Psychiatry 74, 1200-1205.

[19] Patel NS, Paris D, Mathura V, Quadros AN, Crawford FC, Mullan MJ (2005) Inflammatory cytokine levels correlate with amyloid load in transgenic mouse models of Alzheimer's disease. J Neuroinflammation 2, 9.

[20] Millington C, Sonego S, Karunaweera N, Rangel A, Aldrich-Wright JR, Campbell IL, Gyengesi E, Münch G (2014) Chronic neuroinflammation in Alzheimer's disease: New perspectives on animal models and promising candidate drugs. Biomed Res Int 2014, 309129.

[21] Reale M, D’Angelo C, Costantini E, Di Nicola M, Yarla NS, Kamal MA, Salvador N, Perry G (2018) Expression profiling of cytokine, cholinergic markers, and amyloid$\beta$ deposition in the APPSWE/PS1dE9 mouse model of Alzheimer's disease pathology. J Alzheimers Dis 62, 467-476.

[22] Riphagen JM, Ramakers IHGM, Freeze WM, Pagen LHG, Hanseeuw BJ, Verbeek MM, Verhey FRJ, Jacobs HIL (2020) Linking APOE- $\varepsilon$ 4, blood-brain barrier dysfunction, and inflammation to Alzheimer's pathology. Neurobiol Aging 85, 96-103.

[23] Anderson AC, Reddy J, Nazareno R, Sobel RA, Nicholson LB, Kuchroo VK (2004) IL-10 plays an important role in 
the homeostatic regulation of the autoreactive repertoire in naive mice. J Immunol 173, 828-834.

[24] Maynard CL, Weaver CT (2008) Diversity in the contribution of interleukin-10 to T-cell-mediated immune regulation. Immunol Rev 226, 219-233.

[25] Miró-Mur F, Urra X, Ruiz-Jaén F, Pedragosa J, Chamorro Á, Planas AM (2020) Antigen-dependent T cell response to neural peptides after human ischemic stroke. Front Cell Neurosci 3, 206.

[26] Lio D, Licastro F, Scola L, Chiappelli M, Grimaldi LM, Crivello A, Colonna-Romano G, Candore G, Franceschi C, Caruso C (2003) Interleukin-10 promoter polymorphism in sporadic Alzheimer's disease. Genes Immun 4, 234-238.

[27] Li W, Qian X, Teng H, Ding Y, Zhang L (2014) Association of interleukin- 4 genetic polymorphisms with sporadic Alzheimer's disease in Chinese Han population. Neurosci Lett 563, 17-21.

[28] Soosanabadi M, Bayat H, Kamali K, Saliminejad K, Banan M, Khorram Khorshid H (2015) Association study of IL$4-590 \mathrm{C} / \mathrm{T}$ and DDX39B -22G/C polymorphisms with the risk of late-onset Alzheimer's disease in Iranian population. Curr Aging Sci 8, 276-281.

[29] Su F, Bai F, Zhang Z (2016) Inflammatory cytokines and Alzheimer's disease: A review from the perspective of genetic polymorphisms. Neurosci Bull 32, 469-480.

[30] Mun MJ, Kim JH, Choi JY, Jang WC (2016) Genetic polymorphisms of interleukin genes and the risk of Alzheimer's disease: An update meta-analysis. Meta Gene 8, 1-10.

[31] Babić Leko M, Nikolac Perković M, Klepac N, Štrac DŠ, Borovečki F, Pivac N, Hof PR, Šimić G (2020) IL-1 $\beta$, IL6 , IL-10, and TNF $\alpha$ single nucleotide polymorphisms in human influence the susceptibility to Alzheimer's disease pathology. J Alzheimers Dis 75, 1029-1047.

[32] Wolff JA, Ludtke JJ, Acsadi G, Williams P, Jani A (1992) Long-term persistence of plasmid DNA and foreign gene expression in mouse muscle. Hum Mol Genet 1, 363-369.

[33] Matsumoto Y, Niimi N, Kohyama K (2013) Development of a new DNA vaccine for Alzheimer disease targeting a wide range of a $\beta$ species and amyloidogenic peptides. PLoS One 8, e75203.

[34] Martins YA, Tsuchida CJ, Antoniassi P, Demarchi IG (2017) Efficacy and safety of the immunization with DNA for Alzheimer's disease in animal models: A systematic review from literature. J Alzheimers Dis Rep 1, 195-217.

[35] Suschak JJ, Williams JA, Schmaljohn CS (2017) Advancements in DNA vaccine vectors, non-mechanical delivery methods, and molecular adjuvants to increase immunogenicity. Hum Vaccin Immunother 13, 2837-2848.

[36] Zhou B, Kermany MH, Cai Q, Cai C, Zhou Y, Nair U, Liu W, Yoo TJ (2012) Experimental autoimmune hearing loss is exacerbated in IL-10-deficient mice and reversed by IL-10 gene transfer. Gene Ther 19, 228-235.

[37] Hsiao K, Chapman P, Nilsen S, Eckman, C, Harigaya Y, Younkin S, Yang F, Cole G (1996) Correlative memory deficits, Abeta elevation, and amyloid plaques in transgenic mice. Science 274, 99-102.

[38] Wolff JA, Malone RW, Williams P, Chong W, Acsadi G, Jani A, Felgner PL (1990) Direct gene transfer into mouse muscle in vivo. Science 247, 1465-1468.

[39] Raz E, Carson DA, Parker SE, Parr TB, Abai AM, Aichinger G, Gromkowski SH, Singh M, Lew D, Yankauckas MA (1994) Intradermal gene immunization: The possible role of DNA uptake in the induction of cellular immunity to viruses. Proc Natl Acad Sci U S A 91, 9519-9523.
[40] Sato Y, Roman M, Tighe H, Lee D, Corr M, Nguyen MD, Silverman GJ, Lotz M, Carson DA, Raz E (1996) Immunostimulatory DNA sequences necessary for effective intradermal gene immunization. Science 273, 352-354.

[41] Wivel NA, Wilson JM (1998) Methods of gene delivery. Hematol Oncology Clin North Am 12, 483-501.

[42] Yoo TJ (2013) Treatment and prevention of neurodegenerative diseases using gene therapy. United States Patent $8,247,385$ B2.

[43] Kwon SS, Kim N, Yoo TJ (2001) The effect of vaccination with DNA encoding murine T-cell epitopes on the Der $\mathrm{p}$ 1 and 2 induced immunoglobulin E synthesis. Allergy 56, 741-748.

[44] Morris R (1984) Developments of a water-maze procedure for studying spatial learning in the rat. J Neurosci Methods 11, 47-60.

[45] R Core Team (2013) R: A language and environment for statistical computing. Vienna, Austria: R Foundation for Statistical Computing. Retrieved from http://www.Rproject.org (accessed on July 13, 2021).

[46] Drummond E, Wisniewski T (2017) Alzheimer's disease: Experimental models and reality. Acta Neuropathol 133, 155-175.

[47] Stewart S, Cacucci F, Lever C (2011) Which memory task for my mouse? A systematic review of spatial memory performance in the $\mathrm{Tg} 2576$ Alzheimer's mouse model. $J$ Alzheimers Dis 26, 105-126.

[48] Zahs KR, Ashe KH (2010) 'Too much good news' - are Alzheimer mouse models trying to tell us how to prevent, not cure, Alzheimer's disease? Trends Neurosci 33, 381-389.

[49] Schenk D (2002) Amyloid-beta immunotherapy for Alzheimer's disease: The end of the beginning. Nat Rev Neurosci 3, 824-828.

[50] Hung, SY, Fu, WM (2017) Drug candidates in clinical trials for Alzheimer's disease. J Biomed Sci 24, 47.

[51] Sasaguri H, Nilsson P, Hashimoto S, Nagata K, Saito T, De Strooper B, Hardy J, Vassar R, Winblad B, Saido TC (2017) APP mouse models for Alzheimer's disease preclinical studies. EMBO J 36, 2473-2487.

[52] Cacabelos R, Carrera I, Martínez-Iglesias O, Cacabelos $\mathrm{N}$, Naidoo V (2021) What is the gold standard model for Alzheimer's disease drug discovery and development? Expert Opin Drug Discov 25, 1-26.

[53] Myers A, McGonigle P (2019) Overview of transgenic mouse models for Alzheimer's disease. Curr Protoc Neurosci $\mathbf{8 9}$, e81.

[54] Kiyota T, Okuyama S, Swan RJ, Jacobsen MT, Gendelman HE, Ikezu T (2010) CNS expression of anti-inflammatory cytokine interleukin-4 attenuates Alzheimer's disease-like pathogenesis in APP+PS1 bigenic mice. FASEB $J \mathbf{2 4}$, 3093-102.

[55] Kiyota T, Ingraham KL, Swan RJ, Jacobsen MT, Andrews SJ, Ikezu, T (2012) AAV serotype 2/1-mediated gene delivery of anti-inflammatory interleukin-10 enhances neurogenesis and cognitive function in $\mathrm{APP}+\mathrm{PS} 1$ mice. Gene Ther 19, 724-733.

[56] Latta CH, Sudduth TL, Weekman EM, Brothers HM, Abner EL, Popa GJ, Mendenhall MD, Gonzalez-Oregon F, Braun K, Wilcock DM (2015) Determining the role of IL-4 induced neuroinflammation in microglial activity and amyloid- $\beta$ using BV2 microglial cells and APP/PS1 transgenic mice. J Neuroinflammation 12, 41.

[57] Chakrabarty P, Tianbai L, Herring A, Ceballos-Diaz C, Das P, Golde TE (2012) Hippocampal expression of murine IL-4 
results in exacerbation of amyloid deposition. Mol Neurodegener 7, 36 .

[58] Chakrabarty P, Li A, Ceballos-Diaz C, Eddy JA, Funk CC, Moore B, DiNunno N, Rosario AM, Cruz PE, Verbeeck C, Sacino A, Nix S, Janus C, Price ND, Das P, Golde TE (2015) IL-10 alters immunoproteostasis in APP mice, increasing plaque burden and worsening cognitive behavior. Neuron 85, 519-533.

[59] Guillot-Sestier MV, Doty KR, Town T (2015) Innate immunity fights Alzheimer's disease. Trends Neurosci 38, 674-681.

[60] Lentz TB, Gray SJ, Samulski RJ (2012) Viral vectors for gene delivery to the central nervous system. Neurobiol Dis 48,179-88.

[61] Abbas N, Bednar I, Mix E, Marie S, Paterson D, Ljungberg A, Morris C, Winblad B, Nordberg A, Zhu J (2002) Upregulation of the inflammatory cytokines IFN-gamma and IL-12 and down-regulation of IL-4 in cerebral cortex regions of APP(SWE) transgenic mice. J Neuroimmunol 126, 50-57.

[62] Michaud JP, Rivest S (2015) Anti-inflammatory signaling in microglia exacerbates Alzheimer's disease-related pathology. Neuron 85, 450-452.

[63] Sarlus H, Heneka MT (2017) Microglia in Alzheimer's disease. J Clin Invest 127, 3240-3249.

[64] Raikwar SP, Thangavel R, Dubova I, Ahmed ME, Selvakumar PG, Kempuraj D, Zaheer S, Iyer S, Zaheer A (2018) Neuro-immuno-gene- and genome-editing-therapy for Alzheimer's disease: Are we there yet? J Alzheimers Dis 65, 321-344.

[65] Hampel H, Caraci F, Cuello AC, Caruso G, Nisticò R, Corbo M, Baldacci F, Toschi N, Garaci F, Chiesa PA, Verdooner SR, Akman-Anderson L, Hernández F, Ávila J, Emanuele E, Valenzuela PL, Lucía A, Watling M, Imbimbo BP, Vergallo A, Lista $S$ (2020) A path toward precision medicine for neuroinflammatory mechanisms in Alzheimer's disease. Front Immunol 11, 456.

[66] Chen JH, Ke KF, Lu JH, Qiu YH, Peng YP (2015) Protection of TGF- $\beta 1$ against neuroinflammation and neurodegeneration in A $31-42$-induced Alzheimer's disease model rats. PLoS One 10, e0116549.

[67] Komai T, Inoue M, Okamura T, Morita K, Iwasaki Y, Sumitomo S, Shoda H, Yamamoto K, Fujio K (2018) Transforming growth factor- $\beta$ and interleukin-10 synergistically regulate humoral immunity via modulating metabolic signals. Front Immunol 9, 1364.

[68] Kudrna JJ, Ugen KE (2015) Gene-based vaccines and immunotherapeutic strategies against neurodegenerative diseases: Potential utility and limitations. Hum Vaccin Immunother 11, 1921-1926.

[69] Murlidharan G, Sakamoto K, Rao L, Corriher T, Wang D, Gao G, Sullivan P, Asokan A (2016) CNS-restricted transduction and CRISPR/Cas9-mediated gene deletion with an engineered AAV vector. Mol Ther Nucleic Acids 5, e338.

[70] Park H, Oh J, Shim G, Cho B, Chang Y, Kim S, Baek S, Kim H, Shin J, Choi H, Yoo J, Kim J, Jun W, Lee M, Lengner CJ, Oh YK, Kim J (2019) In vivo neuronal gene editing via CRISPR-Cas9 amphiphilic nanocomplexes alleviates deficits in mouse models of Alzheimer's disease. Nat Neurosci 22, 524-528.

[71] Bartee E, McFadden G (2013) Cytokine synergy: An underappreciated contributor to innate anti-viral immunity. Cytokine 63, 237-240.

[72] Ko KS, Lee M, Koh JJ, Kim SW (2001) Combined administration of plasmids encoding IL-4 and IL-10 prevents the development of autoimmune diabetes in nonobese diabetic mice. Mol Ther 4, 313-316.

[73] Eijkelkamp N, Steen-Louws C, Hartgring SA, Willemen HL, Prado J, Lafeber FP, Heijnen CJ, Hack CE, van Roon JA, Kavelaars A (2016) IL4-10 fusion protein is a novel drug to treat persistent inflammatory pain. J Neurosci 36, 7353-7363.

[74] Steen-Louws C, Hartgring SAY, Popov-Celeketic J, Lopes AP, de Smet MBM, Eijkelkamp N, Lafeber FPJG, Hack CE, van Roon JAG (2019) IL4-10 fusion protein: A novel immunoregulatory drug combining activities of interleukin 4 and interleukin 10. Clin Exp Immunol 195, $1-9$.

[75] Li W, Huang E, Gao S (2017) Type 1 diabetes mellitus and cognitive impairments: A systematic review. J Alzheimers Dis 57, 29-36.

[76] Biessels GJ, Despa F (2018) Cognitive decline and dementia in diabetes mellitus: Mechanisms and clinical implications. Nat Rev Endocrinol 14, 591-604.

[77] Newcombe EA, Camats-Perna J, Silva ML, Valmas N, Huat TJ, Medeiros R (2018) Inflammation: The link between comorbidities, genetics, and Alzheimer's disease. J Neuroinflammation 15, 276.

[78] Rea IM, Gibson DS, McGilligan V, McNerlan SE, Alexander HD, Ross OA (2018) Age and age-related diseases: Role of inflammation triggers and cytokines. Front Immunol 9, 586 .

[79] Cao S, Fisher DW, Yu T, Dong H (2019) The link between chronic pain and Alzheimer's disease. J Neuroinflammation 16, 204

[80] King DL, Arendash GW (2002) Behavioral characterization of the $\mathrm{Tg} 2576$ transgenic model of Alzheimer's disease through 19 months. Physiol Behav 75, 627-642.

[81] Wang J, Tanila H, Puoliväli J, Kadish I, van Groen T (2003) Gender differences in the amount and deposition of amyloidbeta in APPswe and PS1 double transgenic mice. Neurobiol Dis 14, 318-327.

[82] Shimazawa M, Inokuchi Y, Okuno T, Nakajima Y, Sakaguchi G, Kato A, Oku H, Sugiyama T, Kudo T, Ikeda T, Takeda M, Hara H (2008) Reduced retinal function in amyloid precursor protein-over-expressing transgenic mice via attenuating glutamate-N-methyl-d-aspartate receptor signaling. J Neurochem 107, 279-290.

[83] Bedrosian TA, Herring KL, Weil ZM, Nelson RJ (2011) Altered temporal patterns of anxiety in aged and amyloid precursor protein (APP) transgenic mice. Proc Natl Acad Sci U S A 108, 11686-11691.

[84] Puzzo D, Gulisano W, Palmeri A, Arancio O (2015) Rodent models for Alzheimer's disease drug discovery. Expert Opin Drug Discov 10, 703-711.

[85] Esquerda-Canals G, Montoliu-Gaya L, Güell-Bosch J, Villegas S (2017) Mouse models of Alzheimer's disease. J Alzheimers Dis 57, 1171-1183.

[86] Sparks DL (2008) The early and ongoing experience with the cholesterol-fed rabbit as a model of Alzheimer's disease: The old, the new and the pilot. JAlzheimers Dis 15, 641-656.

[87] Woodruff-Pak DS (2008) Animal models of Alzheimer's disease: Therapeutic implications. J Alzheimers Dis 15, 507-521.

[88] Sims-Robinson C, Kim B, Rosko A, Feldman EL (2010) How does diabetes accelerate Alzheimer disease pathology? Nat Rev Neurol 6, 551-559.

[89] Marciani DJ (2016) A retrospective analysis of Alzheimer's disease vaccine progress - The critical need for new development strategies. J Neurochem 137, 687-700. 
[90] Lambracht-Washington D, Fu M, Wight-Carter M, Riegel M, Rosenberg RN (2017) Evaluation of a DNA Aß42 vaccine in aged NZW rabbits: Antibody kinetics and immune profile after intradermal immunization with full-length DNA A 342 trimer. J Alzheimers Dis 57, 97-112.

[91] Wolff JA, Budker V (2005) The mechanism of naked DNA uptake and expression. Adv Genet 54, 3-20.
[92] Jayant RD, Sosa D, Kaushik A, Atluri V, Vashist A, Tomitaka A, Nair M (2016) Current status of non-viral gene therapy for CNS disorders. Expert Opin Drug Deliv 13, 1433-1445.

[93] Kumar SR, Markusic DM, Biswas M, High KA, Herzog RW (2016) Clinical development of gene therapy: Results and lessons from recent successes. Mol Ther Methods Clin Dev 3, 16034. 